\title{
Increased levels of airway neutrophils reduce the inhibitory effects of inhaled glucocorticosteroids on allergen-induced airway eosinophils
}

\author{
Gail M Gauvreau PhD, Mark D Inman PhD MD, Margaret Kelly MD, \\ Richard M Watson BSc, Sandra C Dorman BSc, Paul M O'Byrne MB FRCPI FRCPC
}

GM Gauvreau, MD Inman, M Kelly, RM Watson, SC Dorman, PM O'Byrne. Increased levels of airway neutrophils reduce the inhibitory effects of inhaled glucocorticosteroids on allergen-induced airway eosinophils. Can Respir J 2002;9(1):26-32.

BACKGROUND: Treatment with inhaled glucocorticosteroids attenuates allergen-induced airway inflammation but is less effective in people with asthma who have noneosinophilic airway inflammation.

OBJECTIVE: Studies in which glucocorticosteroid treatment was used before allergen challenges were re-examined to determine whether the efficacy of steroid treatment could be predicted by baseline levels of sputum inflammatory cells.

PATIENTS AND METHODS: Twenty-eight nonsmoking subjects with atopic asthma controlled by beta ${ }_{2}$-agonists participated in only one of three studies, each carried out with a double-blind, placebo controlled, randomized, crossover design. Subjects were treated with glucocorticosteroids or placebo for six to eight days and then underwent allergen inhalation challenge. Spirometry was measured for $7 \mathrm{~h}$ after allergen challenge, and then sputum inflammatory cells were measured. Sputum inflammatory cells were also measured before and after treatment, and $24 \mathrm{~h}$ after allergen challenge. The per cent inhibition of the allergeninduced airway responses by glucocorticosteroids was calculated. RESULTS: Inhaled gluticocorticosteroids significantly attenuated the early and late asthmatic responses, and the number of allergeninduced sputum eosinophils $(\mathrm{P}<0.05)$. There was a significant negative relationship between the number of sputum neutrophils at baseline, and the per cent inhibition of allergen-induced sputum eosinophils measured at $7 \mathrm{~h}(\mathrm{r}=-0.61, \mathrm{P}<0.001)$ and $24 \mathrm{~h}(\mathrm{r}=-0.73$, $\mathrm{P}<0.0001$ ) after challenge, suggesting that glucocorticosteroids are less effective in attenuating allergen-induced airway inflammation in subjects with high levels of neutrophils. There was no correlation between the number of sputum eosinophils at baseline and the per cent inhibition of allergen-induced responses.

CONCLUSIONS: Baseline airway neutrophils, not eosinophils, can be used to predict the efficacy of inhaled steroids on allergeninduced sputum eosinophils.

Key Words: Airway inflammation; Allergen inhalation; Eosinophils; Glucocorticosteroids; Neutrophils; Sputum induction

Résumé à la page suivante

Asthma Research Group, St Joseph's Hospital and the Department of Medicine, McMaster University, Hamilton, Ontario

Correspondence and reprints: Dr PM O'Byrne, Firestone Chest and Allergy Unit, Room R113, St Joseph's Hospital, 50 Charlton Avenue East,

Hamilton, Ontario L8N 4A6. Telephone 905-522-1155 ext 3694, fax 905-521-6125, e-mail obyrnep@mcmaster.ca 


\section{Des taux élevés de polynucléaires neutrophiles dans les voies respiratoires réduisent l'effet inhibiteur des glucocorticoïdes en aérosol sur les éosinophiles d'origine allergique}

CONTEXTE : Les glucocorticoïdes en aérosol atténuent l'inflammation des voies aériennes d'origine allergique, mais ils sont moins efficaces chez les asthmatiques qui présentent une inflammation non éosinophile des voies respiratoires.

OBJECTIF : Passer en revue les études dans lesquelles le traitement aux glucocorticoïdes a été administré avant la réalisation des tests de provocation pour vérifier si on peut prévoir l'efficacité des stéroïdes à partir du nombre initial de cellules inflammatoires dans les sécrétions.

PATIENTS ET MÉTHODE : Vingt-huit sujets non fumeurs, souffrant d'asthme atopique maîtrisé par les agonistes bêta ${ }_{2}$ ont participé à l'une des trois études seulement; toutes ont été menées à double insu, contre placebo, avec répartition aléatoire et permutation. Les sujets ont été traités aux glucocorticoïdes ou par placebo durant six à huit jours, puis soumis à un test de provocation inhalatoire. On a procédé à des mesures de la spirométrie pendant 7 heures après le test de provocation, puis à celle des cellules inflammatoires dans les expectorations. Il y a également eu mesure de ces cellules avant et après le traitement ainsi que $24 \mathrm{~h}$ après le test de provocation. On a aussi calculé le pourcentage d'inhibition des réactions allergiques dans les voies respiratoires, attribuable aux glucocorticoïdes.

RÉSULTATS : Les glucocorticoïdes en aérosol ont permis d'atténuer sensiblement les réactions asthmatiques précoces et tardives et de réduire significativement le nombre d'éosinophiles d'origine allergique dans les expectorations $(\mathrm{P}<0,05)$. On a constaté l'existence d'une relation négative importante entre le nombre de neutrophiles au départ et le pourcentage d'inhibition d'éosinophiles d'origine allergique dans les sécrétions, mesuré $7 \mathrm{~h}(\mathrm{r}=-0,61 ; \mathrm{P}<0,001)$ et 24 h $(\mathrm{r}=-0,73 ; \mathrm{P}<0,0001)$ après le test de provocation, ce qui donne à penser que les glucocorticoïdes sont moins efficaces pour atténuer l'inflammation d'origine allergique dans les voies respiratoires chez les sujets qui présentent des taux élevés de neutrophiles. Il n'y avait pas de corrélation entre le nombre d'éosinophiles dans les sécrétions au départ et le pourcentage d'inhibition des réactions de nature allergique.

CONCLUSION : Le nombre de neutrophiles, mais pas celui d'éosinophiles, dans les expectorations au départ peut servir à prévoir l'efficacité des stéroïdes en aérosol sur les éosinophiles d'origine allergique dans les sécrétions.
A sthma is well recognized as an inflammatory disorder of the airways characterized by increased levels of eosinophils $(1,2)$. Eosinophils have been shown to be sensitive to the effects of gluticorticoids, because treatment with glucocorticoids has been shown to reduce the level of eosinophils in the peripheral blood $(3,4)$ and airways of individuals with asthma (5), and to inhibit the allergeninduced increased levels of eosinophils in the peripheral blood and airways (6-8). The level of sputum eosinophils has been shown to predict the clinical benefit of steroid treatment for people with asthma $(9,10)$.

Although eosinophils are considered to be the hallmark of asthmatic airway inflammation, there is increasing evidence that neutrophils may also play a prominent role. Elevated levels of neutrophils have been measured in the airways of subjects with stable asthma (11), during exacerbations of asthma (12) and in fatal asthma of sudden onset (13). Glucocorticoids are reported to be less effective in people with asthma who have noneosinophilic airway inflammation (14), and we hypothesize that neutrophil levels may also be used to predict the magnitude of benefit as a result of steroid treatment. Thus, the aim of the present study was to reexamine studies in which steroid treatment was used in allergen challenge to determine whether allergic responses or the efficacy of steroid treatment could be predicted by baseline levels of inflammatory cells in induced sputum.

\section{PATIENTS AND METHODS}

\section{Patients}

Twenty-eight patients with mild atopic asthma each participated in one of three studies (6-8) approved by the Ethics Committee of the McMaster University Health Sciences Centre (Hamilton, Ontario). Each of these studies demonstrated significant inhibition of the allergen-induced late asthmatic response (LAR) and sputum eosinophils after regular glucocorticoid treatment, but did not examine the relationship between the baseline number of sputum neutrophils and efficacy of glucocorticoid treatment.

Nonsmoking subjects between the ages of 18 and 65 years were recruited for the studies (Table 1). All sub-

\section{TABLE 1}

Mean (range) characteristics for 28 patients with mild atopic asthma

\begin{tabular}{|c|c|c|c|}
\hline & $\begin{array}{c}\text { Study } 1 \\
200 \mu \mathrm{g} \text { budesonide } \\
\text { twice daily for eight days }\end{array}$ & $\begin{array}{c}\text { Study } 2 \\
200 \mu g \text { budesonide } \\
\text { twice daily for seven days }\end{array}$ & $\begin{array}{c}\text { Study } 3 \\
400 \mu g \text { mometsone } \\
\text { twice daily for six days }\end{array}$ \\
\hline Age (years) & $24.8(21,37)$ & $21.2(19,24)$ & $26.8(18,45)$ \\
\hline $\mathrm{FEV}_{1}(\%$ predicted $)$ & $86.6(77.9,97.8)$ & $82.2(70.6,96.3)$ & $89.3(77.2,107.7)$ \\
\hline $\mathrm{MCh} \mathrm{PC}_{20}(\mathrm{mg} / \mathrm{mL})$ & $1.7(0.4,6.3)$ & $1.1(0.2,19.9)$ & $1.55(0.2,8.4)$ \\
\hline LAR placebo (\% change) & $-23.4(-3.2,-38.3)$ & $-23.7(-9.2,-44.3)$ & $-23.5(-1.1,-50.0)$ \\
\hline LAR glucocorticoid ( $\%$ change) & $-4.6(-12.5,0)$ & $-6.6(-15.2,+3.4)$ & $-5.9(-15.2,+6.5)$ \\
\hline
\end{tabular}

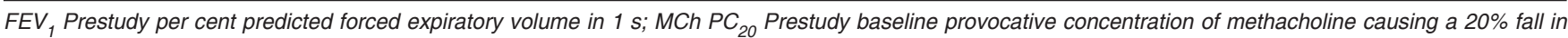

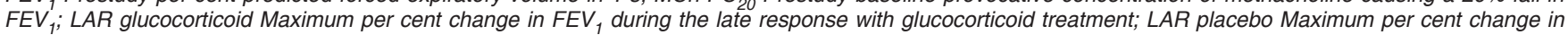
$F E V_{1}^{1}$ during the late response with placebo treatment 
jects had documented allergen-induced early asthmatic response (EAR) and LAR of an at least 15\% fall in forced expiratory volume in $1 \mathrm{~s}\left(\mathrm{FEV}_{1}\right)$, gave signed consent to participate, and were randomizly assigned to inhale glucocorticosteroid and placebo for six to eight days. Subjects did not have asthma exacerbations or respiratory tract infections and were not knowingly exposed to altered levels of sensitizing allergens for at least four weeks before entering the studies. All subjects had stable asthma with a baseline $\mathrm{FEV}_{1}$ greater than $70 \%$ of predicted normal on all of the study days before allergen inhalation. Subjects used no medication other than inhaled beta $_{2}$-agonists as required to treat their symptoms, and beta $_{2}$-agonists were withheld for at least $8 \mathrm{~h}$ before each visit. Subjects were instructed to refrain from vigorous exercise and caffeine in the mornings before visits to the laboratory. Four subjects were excluded two experienced deterioration of their asthma, one was unable to inhale the same dose of allergen during the two challenges and one was not available to complete the second allergen challenge.

\section{Study design}

Three studies were carried out with a double-blind, placebo controlled, randomized, crossover design. The subjects were randomly assigned to complete two treatment periods inhaling: $200 \mu \mathrm{g}$ budesonide or placebo twice daily for eight days, with the last dose of drug taken the morning of allergen challenge (study $1, \mathrm{n}=8$ ), or for seven days, with the last dose of drug taken $12 \mathrm{~h}$ before allergen challenge (study 2 , $\mathrm{n}=7$ ); or $400 \mu \mathrm{g}$ mometasone furoate or placebo twice daily for six days, with the last dose of drug taken $24 \mathrm{~h}$ after allergen challenge (study $3, \mathrm{n}=9$ ) (Figure 1). Each treatment period consisted of four visits to the laboratory. Baseline measurements of $\mathrm{FEV}_{1}$, the provocative concentration of methacholine causing a $20 \%$ fall in $\mathrm{FEV}_{1}\left(\mathrm{PC}_{20}\right)$, and induced sputum total and differential cell counts were determined before receiving treatment, and again at $24 \mathrm{~h}$ before allergen challenge, $7 \mathrm{~h}$ after allergen challenge and $24 \mathrm{~h}$ after allergen challenge. Allergen inhalation challenges were carried out in the morning, and spirometry was measured for $7 \mathrm{~h}$. Treatment periods were separated by a washout period of at least three weeks.

\section{Interventions}

Methacholine inhalation test: The methacholine inhalation challenge was performed as described by Cockcroft (15). Subjects inhaled normal saline and were then administered double the concentrations of methacholine phosphate (ACIC Fine Chemicals Inc, Canada) from a Wright nebulizer (Roxon Medi-Tech Ltd, Canada) via a Hans Rudolph valve (Hans Rudolph Inc, USA) for 2 min. FEV was measured at 30, 90, 180 and $300 \mathrm{~s}$ with a Collins water sealed spirometer and kymograph (Warren Collins, USA). The test was terminated when a fall in $\mathrm{FEV}_{1}$ of $20 \%$ of the postsaline value occurred, and the $\mathrm{PC}_{20}$ was calculated.

Allergen inhalation challenge: Allergen challenge was performed as described by O'Byrne and coworkers (16). The

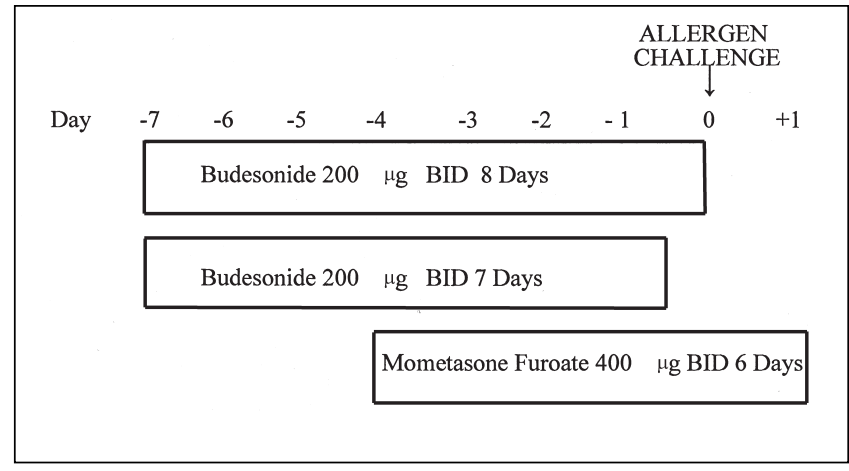

Figure 1) Schematic diagram demonstrating dosing schedule of glucocorticosteroids - $200 \mu \mathrm{g}$ of budesonide inhaled twice daily (BID) for eight days, with the last dose inhaled 30 min before allergen inhalation; $200 \mu \mathrm{g}$ of budesonide inhaled twice daily for seven days, with the last dose inhaled $12 \mathrm{~h}$ before allergen inhalation; $400 \mu \mathrm{g}$ of mometasone furoate inhaled twice daily for six days, with the last dose of drug taken $24 \mathrm{~h}$ after allergen challenge

starting allergen extract concentration inhaled by each subject was determined from a formula using the results from the skin test and the methacholine $\mathrm{PC}_{20}$ (17). Allergen inhalation challenges were performed using a Wright nebulizer pressurized by air at 50 pounds per square inch, and at a flow rate that gave an output of $0.13 \mathrm{~mL} / \mathrm{min}$ and an aerodynamic mass median diameter of 1.0 to $1.5 \mu \mathrm{m}$. Concentrations of allergen were inhaled by tidal breathing (nose clipped) for $2 \mathrm{~min}$, with the $\mathrm{FEV}_{1}$ measured $10 \mathrm{~min}$ after each inhalation. Subjects inhaled the same concentration of allergen for both challenges, resulting in a greater than $15 \%$ EAR and LAR during a previous screening period. $\mathrm{FEV}_{1}$ was subsequently measured at 20, 30, 45, 60, 90 and $120 \mathrm{~min}$, and at hourly intervals up to $7 \mathrm{~h}$ postallergen inhalation using a water-sealed spirometer. The EAR was taken to be the largest fall in $\mathrm{FEV}_{1}$ within $2 \mathrm{~h}$ after allergen inhalation, and the LAR was taken to be the largest fall in $\mathrm{FEV}_{1}$ between 3 and $7 \mathrm{~h}$ after allergen inhalation.

Sputum induction: Sputum was induced and processed using the method described by Pizzichini and coworkers (18). Sputum cell plugs were mixed with a bench rocker in $0.1 \%$ dithiothreitol (Sputolysin; Calbiochem Corporation, USA) and Dulbecco's phosphate buffered saline (Life Technologies [Gibco BRL], USA), filtered through a $52 \mu \mathrm{m}$ pore nylon gauze (BNSH Thompson, Canada) and then centrifuged at $1571 \mathrm{rad} / \mathrm{s}$ for $10 \mathrm{~min}$. Cells were resuspended in Dulbecco's phosphate buffered saline at 0.75 to $1.0 \times 10^{6} / \mathrm{mL}$, and cytospins were prepared on glass slides using a Shandon 3 cytocentrifuge (Shandon Southern Instruments, USA). Differential cell counts were obtained from the mean of two slides, with 400 cells counted per slide stained with Diff Quik staining solution (American Scientific Products, USA). The sputum cell measurements are presented as absolute numbers to eliminate the possibility that observed changes in a cell population are a result of increases or decreases in another cell population. 


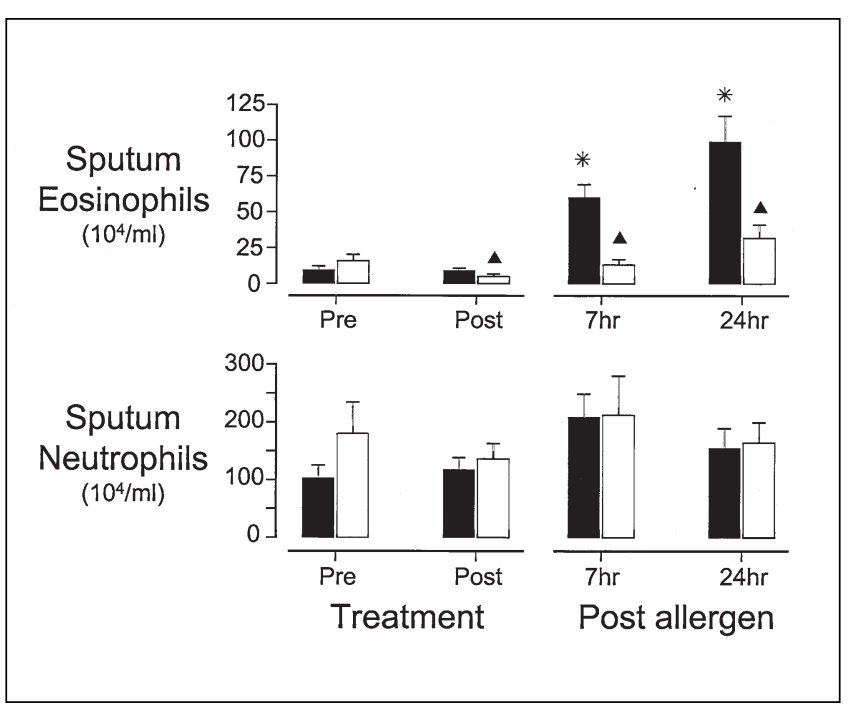

Figure 2) Number of sputum eosinophils (top) and neutrophils (bottom) before treatment, after treatment (solid bars) or placebo (open bars), and at 7 and $24 \mathrm{~h}$ after allergen inhalation $(* P<0.05$ allergeninduced increase from post-treatment baseline; $\boldsymbol{\Delta} P<0.05$ significant effect of glucocorticoid compared with placebo)

\section{Statistical analyses}

Summary statistics are expressed as mean and SEM, with the exception of methacholine $\mathrm{PC}_{20}$ measurements, which are made by linear interpolation of $\log$ dose response curves. Values for methacholine $\mathrm{PC}_{20}$ are expressed as geometric mean and geometric SEM (GSEM). Methacholine $\mathrm{PC}_{20}$ data were analyzed for the effects of allergen and active treatment using repeated measures ANOVA. Single time point comparisons of per cent fall in $\mathrm{FEV}_{1}$ were analyzed using two-tailed Student's paired $t$ test. The per cent inhibition of EAR, LAR and allergen-induced eosinophils was calculated using the equation:

$\%$ inhibition $=($ placebo - steroid $) /$ placebo $\times 100$

The relationship between baseline sputum inflammatory cells and per cent inhibition of allergen-induced responses was examined by the Pearson correlation coefficient; baseline cell counts were calculated as the mean values of the preplacebo and preactive drug measurements.

\section{RESULTS}

The efficacy of inhaled budesonide and mometasone furoate on allergen-induced EAR, LAR, methacholine airway responsiveness and sputum eosinophils has been presented separately elsewhere (6-8), and these data are pooled and summarized below.

The maximum early fall in $\mathrm{FEV}_{1}$ was $-33.7 \% \pm 2.0 \%$ with placebo and $-18.9 \% \pm 2.7 \%(\mathrm{P}<0.001)$ with active treatment, corresponding to a mean inhibition of $44.4 \% \pm 6.9 \%$. Similarly, the early area under the curve was inhibited by $45.8 \% \pm 7.8 \%(\mathrm{P}<0.001)$. The maximum late fall in $\mathrm{FEV}_{1}$ was $-25.4 \% \pm 2.4 \%$ with placebo and $-5.9 \% \pm 1.1 \%$ with active treatment $(\mathrm{P}<0.001)$, a $70.0 \% \pm 6.8 \%$ inhibition of the late response. The late area under the curve was inhibited by $77.4 \% \pm 10.0 \%(\mathrm{P}<0.001)$.

The methacholine $\mathrm{PC}_{20}$ increased from $1.5 \mathrm{mg} / \mathrm{mL}$ ( $1.3 \mathrm{mg} / \mathrm{mL}$ GSEM) to $2.6 \mathrm{mg} / \mathrm{mL}$ (1.3 mg/mL GSEM) after active treatment $(\mathrm{P}=0.002)$, but did not change after placebo treatment, being $1.3 \mathrm{mg} / \mathrm{mL}$ ( $1.3 \mathrm{mg} / \mathrm{mL}$ GSEM) before and $1.8 \mathrm{mg} / \mathrm{mL}(1.4 \mathrm{mg} / \mathrm{mL}$ GSEM $)$ after $(\mathrm{P}=0.11)$. There was a decrease in methacholine $\mathrm{PC}_{20} 24 \mathrm{~h}$ after allergen inhalation with placebo treatment, at which time the $\mathrm{PC}_{20}$ was $0.7 \mathrm{mg} / \mathrm{mL}(1.4 \mathrm{mg} / \mathrm{mL}$ GSEM) ( $\mathrm{P}=0.002$ compared with preallergen, post-treatment value), but this effect of allergen was not apparent with active treatment, with the $\mathrm{PC}_{20}$ being $1.9 \mathrm{mg} / \mathrm{mL}(1.3 \mathrm{mg} / \mathrm{mL}$ GSEM) $(\mathrm{P}=0.06)$.

Inhalation of glucocorticoids for four (mometasone furoate), seven and eight days (budesonide) significantly reduced the number of sputum eosinophils from $15.8 \pm 4.6 \times 10^{4} / \mathrm{mL}$ to $4.9 \pm 1.8 \times 10^{4} / \mathrm{mL}(\mathrm{P}=0.004)$ compared with the placebo group in which there was no change, from $9.3 \pm 2.9 \times 10^{4} / \mathrm{mL}$ before to $9.0 \pm 1.8 \times 10^{4} / \mathrm{mL}$ after $(\mathrm{P}=0.76)$ (Figure 2). There was no significant effect of glucocorticoids on the number of sputum neutrophils, of which there were $179.5 \pm 54.9 \times 10^{4} / \mathrm{mL}$ before and $135.9 \pm 26.8 \times 10^{4} / \mathrm{mL}$ after active treatment compared with $102.8 \pm 22.4 \times 10^{4} / \mathrm{mL}$ before and $117.2 \pm 20.5 \times 10^{4} / \mathrm{mL}$ after placebo $(\mathrm{P}=0.23)$ (Figure 2 ).

Sputum eosinophils increased from $9.0 \pm 1.8 \times 10^{4} / \mathrm{mL}$ to $60.3 \pm 9.0 \times 10^{4} / \mathrm{mL}$ at $7 \mathrm{~h}$ and $99.2 \pm 18.0 \times 10^{4} / \mathrm{mL}$ at $24 \mathrm{~h}$ after allergen inhalation in the placebo group $(\mathrm{P}<0.0002)$. The allergen-induced increase in sputum eosinophil numbers was significantly inhibited with active treatment $(\mathrm{P}<0.0003)$; there were $13.2 \pm 3.8 \times 10^{4} / \mathrm{mL}$ at $7 \mathrm{~h}$ and $31.9 \pm 9.2 \times 10^{4} / \mathrm{mL}$ at $24 \mathrm{~h}$ after allergen inhalation, corresponding to a $71 \%$ and $47 \%$ inhibition of allergen-induced eosinophils at 7 and $24 \mathrm{~h}$, respectively (Figure 2 ). There was no effect of allergen inhalation on sputum neutrophils - $117.2 \pm 20.5 \times 10^{4} / \mathrm{mL}$ before, $208.4 \pm 40.4 \times 10^{4} / \mathrm{mL}$ at $7 \mathrm{~h}$ and $154.8 \pm 34.8 \times 10^{4} / \mathrm{mL}$ at $24 \mathrm{~h}$ after allergen inhalation $(\mathrm{P}>0.30)$ (Figure 2).

Individual baseline sputum neutrophils values were within a wide range from $10.1 \times 10^{4} / \mathrm{mL}$ to $705.4 \times 10^{4} / \mathrm{mL}$. Baseline sputum neutrophil numbers were taken to be the average between predrug and preplacebo values. Baseline sputum neutrophil numbers negatively correlated with per cent inhibition of allergen-induced sputum eosinophils by glucocorticoids at $7 \mathrm{~h}(\mathrm{r}=-0.61, \mathrm{P}<0.001)$ and $24 \mathrm{~h}$ $(r=-0.73, P<0.0001)$ (Figure 3), indicating that glucocorticoids are less effective in reducing allergen-induced airway eosinophils in patients with asthma with higher levels of airway neutrophils. There was no relationship between baseline sputum eosinophils and per cent inhibition of allergeninduced eosinophilia $(\mathrm{P}>0.12)$, indicating that the number of airway eosinophils does not predict the efficacy of glucocorticoids to inhibit allergen-induced airway eosinophilia.

Per cent inhibition of the LAR by glucocorticoids correlated with per cent inhibition of sputum eosinophils at $7 \mathrm{~h}$ $(\mathrm{r}=0.44, \mathrm{P}=0.03)$ and $24 \mathrm{~h}(\mathrm{r}=0.53, \mathrm{P}=0.008)$, indicating an association between airway physiology and sputum eosinophilia. There was no relationship between baseline sputum eosinophils or neutrophils and per cent inhibition 
of the EAR or LAR ( $>0.05)$. No significant correlations between inhibition of airway responses and baseline neutrophil levels were observed when cell populations were expressed as percentages.

\section{DISCUSSION}

It has been reported that sputum eosinophilia may be a predictor of clinical benefit to steroid treatment $(9,19)$; however, the association between sputum neutrophilia and reduced protection by glucocorticoids has not yet been reported. Allergen inhalation challenge in dual responding patients with atopic asthma results in EARs and LARs, and airway eosinophilia (20), which are significantly attenuated by treatment with inhaled glucocorticoids (6-8). The magnitude of allergen-induced airway responses and per cent inhibition by glucocorticoids, however, varies considerably between individuals. We hypothesized that this variability may be due to the underlying level of specific inflammatory cells in the airway. These data examine the relationship between the number of inflammatory cells in the unchallenged airway compared with the magnitude of allergeninduced airway inflammation and inhibition of this inflammation by glucocorticoids.

The data presented here are from three separate and already published studies (6-8). Different subjects and designs were used in each study. For this reason, comparisons between the efficacy of the different treatment types and doses were not made and should not be inferred. The sole purpose of pooling these data in the present study is to examine the hypothesis that treatment efficacy (regardless of steroid type or dose) is predicted by baseline inflammatory markers in sputum.

We have demonstrated that allergen-induced airway eosinophilia is not related to baseline levels of eosinophils or neutrophils in the airway, suggesting that when subjects are delivered inhaled allergen, resulting in similar EARs and LARs, the underlying airway inflammation does not have an effect on the magnitude of allergen-induced airway inflammation. On the other hand, inhibition of allergen-induced airway eosinophilia by glucocorticoids is negatively related to the baseline levels of neutrophils in the airway. This suggests that glucocorticoid therapy in patients with asthma who have higher numbers of airway neutrophils is less effective for the treatment of allergen-induced airway eosinophilia than in patients with asthma who have lower numbers of airway neutrophils. In addition, these data demonstrate that airway neutrophilia, but not eosinophilia, in subjects with mild asthma may predict efficacy of glucocorticoids in the inhibition of allergen-induced sputum eosinophilia.

The role of the neutrophil in the pathophysiology of allergic asthma is not well understood. Neutrophils can synthesize eosinophil cationic protein (21), which implies that they may also impart some role in tissue damage in the asthmatic airway. Airway neutrophilia is present in acute asthma exacerbations $(12,13)$. Neutrophils have been shown to increase in bronchialveolar lavage fluid after allergen challenge in some studies $(22,23)$, but not in others $(24,25)$.

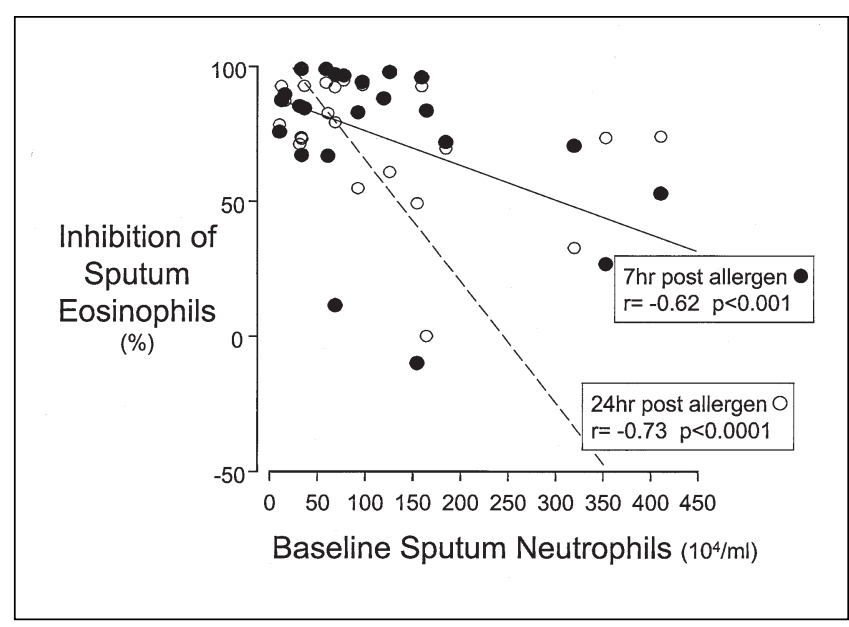

Figure 3) Correlation between baseline sputum neutrophil numbers and per cent inhibition of allergen-induced sputum eosinophils by glucocorticosteroids at $7 \mathrm{~h}(\mathbf{O}$, solid regression line) and $24 \mathrm{~h}(\mathrm{O}$, dashed regression line) after allergen inhalation. For clarity of the figure, two data points measured at $24 \mathrm{~h}$ with inhibition less than $-50 \%$ were not included

Airway eosinophils and neutrophils appear to respond differently to glucocorticoid treatment. Neutrophil levels are found to increase $(26,27)$ or not change (28) after steroid therapy. It is unclear whether airway neutrophils are increased in asthma but are insensitive to the effects of steroids, or whether they are present at elevated levels in some patients with asthma simply as a consequence of long term treatment with steroids and steroid-induced inhibition of neutrophil apoptosis (29). Despite evidence that airway neutrophilia is associated with increased asthma severity $(30,31)$, these earlier studies do not rule out the possibility that neutrophils are present in higher levels in the airways of individuals with more severe asthma, as a direct response to high dose glucocorticoid therapy. In the present study of steroid-naive patients with asthma, neutrophils were not sensitive to the effects of short term treatment (six to eight days) with glucocorticoids, because there was no change in the number of sputum neutrophils after glucocorticoid treatment (6-8). In contrast, there was a significant reduction in the number of sputum eosinophils after glucocorticoid treatment. Thus, it is evident that glucocorticoids can reduce the eosinophil-driven process, while having no effect on the neutrophil-driven process.

In some instances, glucocorticoids have been proposed to enhance neutrophil function $(32,33)$. Neutrophils may actually contribute to the recruitment of eosinophils into the airways through synthesis of various mediators, such as leukotriene $\mathrm{B}_{4}$, cysteinyl leukotrienes, platelet activating factor and elastase, all of which have been shown to have effects that may enhance eosinophilia. Moreover, priming of neutrophils with proinflammatory agents such as granulocyte macrophage colony stimulating factor and tumour necrosis factor-alpha, cytokines known to be generated after allergen inhalation challenge, leads to a significant enhancement of the capacity of neutrophils to produce 5-lipoxygenase prod- 
ucts (34). The neutrophil has a high capacity for synthesis of leukotriene $\mathrm{B}_{4}$, shown to chemoattract eosinophils when they are primed by interleukin-5 (35). Cysteinyl leukotrienes, which may come from airway neutrophils, are capable of inducing airway inflammation $(36,37)$. The lipidderived mediator, platelet activating factor, which is released from airway inflammatory cells, including neutrophils, may contribute to several biological actions relevant to the pathology of airway inflammation, including recruitment and activation of eosinophils (38), and release of mediators such as the cysteinyl leukotrienes from eosinophils (39). The degranulation of eosinophils can be induced by a variety of physiological stimuli, including platelet activating factor (40) and neutrophil elastase (41). The release of neutrophil-derived mediators supports a mechanism by which neutrophils enhance airway eosinophilic inflammation. With airway neutrophils present in elevated numbers and possible activation of neutrophils by glucocorticoids, there lies a mechanism whereby glucocorticoid-insensitive airway neutrophils may participate in accumulating eosinophils in the airways after allergen challenge, despite glucocorticoid intervention.

A surprising finding was that airway neutrophil levels correlated with the per cent inhibition of allergen-induced increases in sputum eosinophils, but not with the per cent inhibition of the LAR. Early studies have described an inverse relationship between airway eosinophils with air-

\section{REFERENCES}

1. Kirby JG, Hargreave FE, Gleich GJ, O’Byrne PM. Bronchoalveolar cell profiles of asthmatic and nonasthmatic subjects.

Am Rev Respir Dis 1987;136:379-83.

2. Pin I, Gibson PG, Kolendowicz R, et al. Use of induced sputum cell counts to investigate airway inflammation in asthma. Thorax 1992;47:25-9.

3. Laviolette L, Ferland C, Trepanier L, Rocheleau H, Dakhama A, Boulet L-P. Effects of inhaled steroids on blood eosinophils in moderate asthma. Ann NY Acad Sci 1994;725:288-97.

4. Evans PM, O'Connor BJ, Fuller RW, Barnes PJ, Chung KF. Effect of inhaled corticosteroids on peripheral blood eosinophil counts and density profiles in asthma. J Allergy Clin Immunol 1993;91:643-50.

5. Claman DM, Boushey HA, Liu J, Wong H, Fahy JV. Analysis of induced sputum to examine the effects of prednisone on airway inflammation in asthmatic subjects. J Allergy Clin Immunol 1994;94:861-9.

6. Gauvreau GM, Doctor J, Watson RM, Jordana M, O'Byrne PM. Effects of inhaled budesonide on allergen-induced airway responses and airway inflammation. Am J Respir Crit Care Med 1996;154:1267-71.

7. Wood LJ, Sehmi R, Gauvreau GM, et al. An inhaled corticosteroid, budesonide, reduces baseline but not allergen-induced increases in bone marrow inflammatory cell progenitors in asthmatic subjects. Am J Respir Crit Care Med 1999;159:1457-63.

8. Inman MD, Watson RM, Rerecich T, et al. Dose-dependent effects of inhaled mometasone furoate on airway function and inflammation after allergen inhalation challenge. Am J Respir Crit Care Med 2001;164:569-74.

9. Pizzichini E, Pizzichini MM, Gibson P, et al. Sputum eosinophilia predicts benefit from prednisone in smokers with chronic obstructive bronchitis. Am J Respir Crit Care Med 1998;158:1511-7.

10. Pavord ID, Brightling CE, Woltmann G, Wardlaw AJ. Non-eosinophilic corticosteroid unresponsive asthma. Lancet 1999;353:2213-4.

11. Lamblin CL, Gosset P, Tillie-Leblond I, et al. Bronchial neutrophilia in patients with noninfectious status asthmaticus. Am J Respir Crit Care Med 1998;157:737-43. way reactivity and bronchoconstriction during asthma exacerbations $(42,43)$, suggesting a causal relationship. More recent studies, however, have provided evidence that the LAR is not necessarily eosinophil-driven. The LAR has been shown to persist despite significant attenuation of sputum eosinophils with an interleukin-5 blocking antibody (44), and the LAR provoked by intradermal injection of peptides is not accompanied by eosinophils in bronchial biopsy specimens (45).

We have shown that airway neutrophil levels, but not eosinophil levels, in individuals with mild asthma may be used to predict the efficacy of inhaled steroids on allergeninduced eosinophilia, and these individuals may benefit from additional anti-inflammatory treatment such as antileukotrienes during exposure to known allergens. We hypothesize that the neutrophil may play an active role in the development of allergen-induced airway eosinophilia due to their insensitivity to the anti-inflammatory effects of steroids, and through their ability to synthesize mediators known to activate and attract eosinophils to the airway. To further test this hypothesis, a formal study is required to confirm that airway neutrophils reduce the benefits of steroids in patients with atopic asthma.

ACKNOWLEDGEMENTS: Financial support for this study was provided by the Canadian Institutes of Health Research.

12. Fahy JV, Kim K, Liu J, Boushey HA. Prominent neutrophilic inflammation in sputum from subjects with asthma exacerbation. J Allergy Clin Immunol 1995;95:843-52.

13. Sur S, Crotty TB, Kephart GM, et al. Sudden-onset fatal asthma: a distinct entity with few eosinophils and relatively more neutrophils in the airway submucosa. Am Rev Respir Dis 1993;148:713-9.

14. Leigh R, Hargreave FE. Occupational neutrophilic asthma. Can Respir J 1999;6:194-6.

15. Cockcroft DM. Measure of airway responsiveness to inhaled histamine or methacholine; method of continuous aerosol generation and tidal breathing inhalation. In: Hargreave FE, Woolcock AJ, eds. Airway Responsiveness: Measurement and Interpretation. Mississauga: Astra Pharmaceuticals Canada Ltd, 1985:22-8.

16. O'Byrne PM, Dolovich J, Hargreave FE. Late asthmatic response. Am Rev Respir Dis 1987;136:740-56.

17. Cockcroft DW, Murdock KY, Kirby J, Hargreave FE. Prediction of airway responsiveness to allergen from skin sensitivity to allergen and airway responsiveness to histamine. Am Rev Respir Dis 1987;135:264-7.

18. Pizzichini E, Pizzichini MMM, Efthimiadis A, et al. Indices of airway inflammation in induced sputum: reproducibility and validity of cell and fluid-phase measurements. Am J Respir Crit Care Med $1996 ; 154: 308-17$

19. Hargreave FE. Induced sputum and response to glucocorticoids. J Allergy Clin Immunol 1998;102:S102-5.

20. Gauvreau GM, Watson RM, O'Byrne PM. Kinetics of allergeninduced airway eosinophilic cytokine production and airway inflammation. Am J Respir Crit Care Med 1999;160:640-7.

21. Leigh R, Belda J, Kelly MM, et al. Eosinophil cationic protein relates to sputum neutrophil counts in healthy subjects. J Allergy Clin Immunol 2000;106:593-4.

22. Metzger WJ, Zavala D, Richerson HB, et al. Local allergen challenge and bronchoalveolar lavage of allergic asthmatic lungs. Description of the model and local airway inflammation. Am Rev Respir Dis 1987;135:433-40.

23. Diaz P, Gonzalez MC, Galleguillos FR, et al. Leukocytes and mediators in bronchoalveolar lavage during allergen-induced 


\section{Gauvreau et al}

late-phase asthmatic reactions. Am Rev Respir Dis 1989;139:1383-9.

24. Aalbers R, Kauffman HF, Vrugt B, Keoter GH, De Monchy JGR. Allergen-induced recruitment of inflammatory cells in lavage 3 and $24 \mathrm{~h}$ after challenge in allergic asthmatic lungs. Chest 1993;103:1178-84.

25. De Monchy JG, Kauffman HF, Venge P, et al. Bronchoalveolar eosinophilia during allergen-induced late asthmatic reactions. Am Rev Respir Dis 1985;131:373-6.

26. Tanizaki Y, Kitani H, Okazaki M, Mifune T, Mitsunobu F, Kimura I. Effects of long-term glucocorticoid therapy on bronchoalveolar cells in adult patients with bronchial asthma. J Asthma 1993;30:309-18.

27. Chanez P, Paradis L, Vignola AM, et al. Changes in bronchial inflammation of steroid (Gcs) dependent asthmatics. Am J Respir Crit Care Med 1996;153:212. (Abst)

28. Moore GE, Mahaffey EA, Hoenig M. Hematologic and serum biochemical effects of long-term administration of anti-inflammatory doses of prednisone in dogs. Am J Vet Res 1992;53:1033-7.

29. Cox G. Glucocorticoid treatment inhibits apoptosis in human neutrophils. J Immunol 1995;154:4719-25.

30. Jatakanon A, Uasuf C, Maxiak W, Lim S, Chung KF, Barnes PF. Neutrophilic inflammation in severe persistent asthma. Am J Respir Crit Care Med 1999;160:1532-9.

31. Wenzel SE, Szefler SJ, Leung DYM, Sloan SI, Rex MD, Martin RJ. Bronchoscopic evaluation of severe asthma. Persistent inflammation associated with high dose glucocorticoids. Am J Respir Crit Care Med 197; 156:737-43.

32. Jaovisidha P, Peeples ME, Brees AA, Carpenter LR, Moy JN. Respiratory syncytial virus stimulates neutrophil degranulation and chemokine release. J Immunol 1999;163:2816-20.

33. Schleimer RP, Freeland HS, Peters SP, Brown KE, Derse CP. An assessment of the effects of glucocorticoids on degranulation, chemotaxis, binding to vascular endothelium and formation of leukotriene $\mathrm{B}_{4}$ by purified human neutrophils. J Pharmacol Exp Ther 1989;250:598-605.

34. Palmantier R, Surette ME, Sanchez A, Braquet P, Borgeat P. Priming for the synthesis of 5-lipoxygenase products in human blood ex vivo by human granulocyte-macrophage colony-stimulating factor and tumor necrosis factor-alpha. Lab Invest 1994;70:696-704.

35. Sehmi R, Wardlaw AJ, Cromwell O, Kurihawa K, Waltmann P, Kay AB. Interleukin-5 selectively enhances the chemotactic response of eosinophils obtained from normal but not eosinophilic subjects. Blood 1992;79:2952-9.

36. Laitenen LA, Laitinen A, Lindqvist A, et al. Effect of zafirlukast (Accolate $\mathrm{tm}$ ) on leukotriene $\mathrm{E}_{4}\left(\mathrm{LTE}_{4}\right)$ induced airway inflammation in asthma. Am J Respir Crit Care Med 1999;159:A642. (Abst)

37. Gauvreau GM, Parameswaran KN, Watson RM, et al. Inhaled leukotriene $\mathrm{e}_{4}$, but not leukotriene $\mathrm{d}_{4}$, increased airway inflammatory cells in subjects with atopic asthma. Am J Respir Crit Care Med 2001;164:1495-500.

38. Barnes PJ, Chung KF, Page CP. Platelet activating factor as a mediator of allergic disease. J Allergy Clin Immunol 1987;81:919-34.

39. Kroegel CT, Yukawa G, Dent G, Venge P, Chung KF, Barnes PJ. Stimulation of degranulation from human eosinophils by platelet-activating factor. J Immunol 1989;142:3518-26.

40. Barnes PJ. PAF, eosinophils, and asthma. J Lipid Mediat 1992;5:155-8.

41. Liu G, Lazarus SC, Caughey GH, Fahy JV. Neutrophil elastase and elastase-rich cystic fibrosis sputum degranulate human eosinophils in vitro. Am J Physiol 1999;276:L28-34.

42. Maestrelli P, Calcagni PG, Saetta M, et al. Sputum eosinophilia after asthmatic responses induced by isocyanates in sensitized subjects. Clin Exp Allergy 1994;24:29-34.

43. Baigelman W, Chodosh S, Piaauto D, Cupples LA. Sputum and blood eosinophils during corticosteroid treatment of acute exacerbations of asthma. Am J Med 1983;75:929-36.

44. Leckie MJ, ten Brinke A, Khan J, et al. Effects of an interleukin-5 blocking monoclonal antibody on eosinophils, airway hyper-responsiveness, and the late asthmatic response. Lancet 2000;356:2114-6.

45. Haselden BM, Larche M, Meng Q, et al. Late asthmatic reactions provoked by intradermal injection of T-cell peptide epitopes are not associated with bronchial mucosal infiltration of eosinophils or $\mathrm{TH}_{2}$-type cells or with elevated concentrations of histamine or eicosanoids in bronchoalveolar fluid. J Allergy Clin Immunol 2001;108:394-401. 


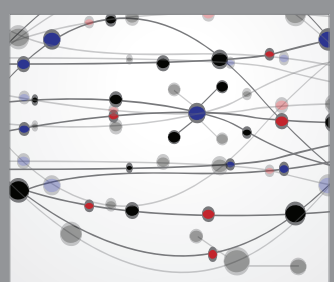

The Scientific World Journal
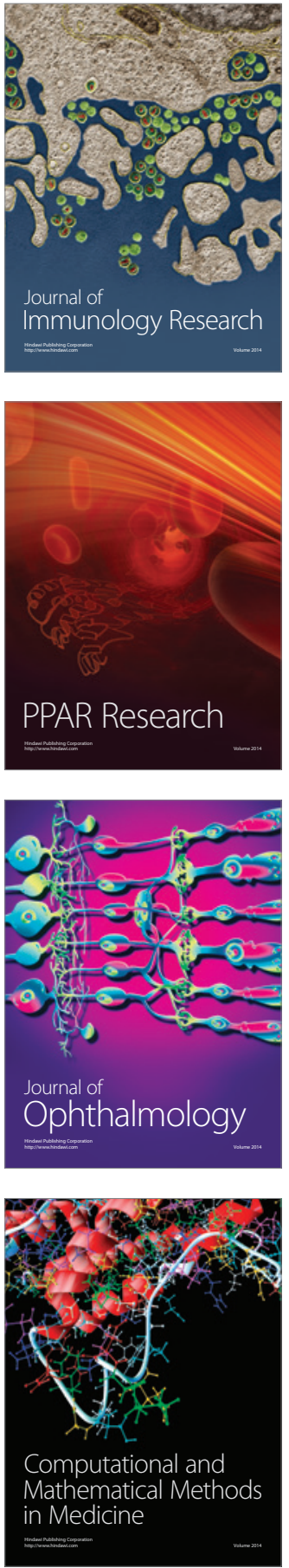

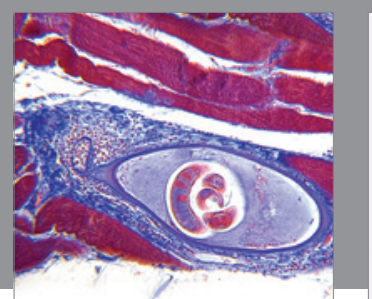

Gastroenterology Research and Practice

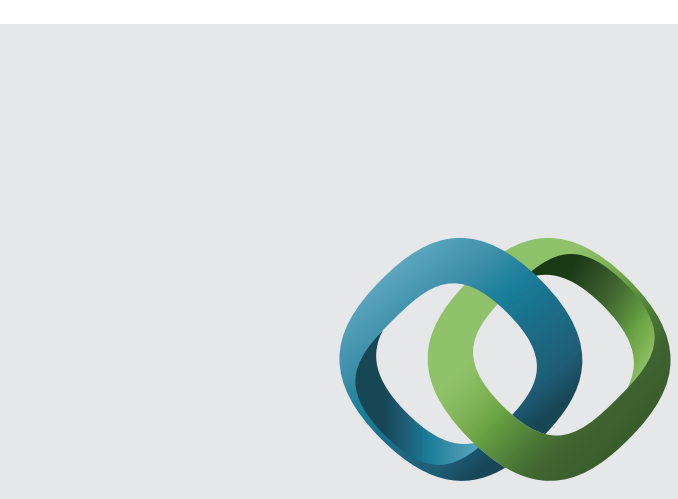

\section{Hindawi}

Submit your manuscripts at

http://www.hindawi.com
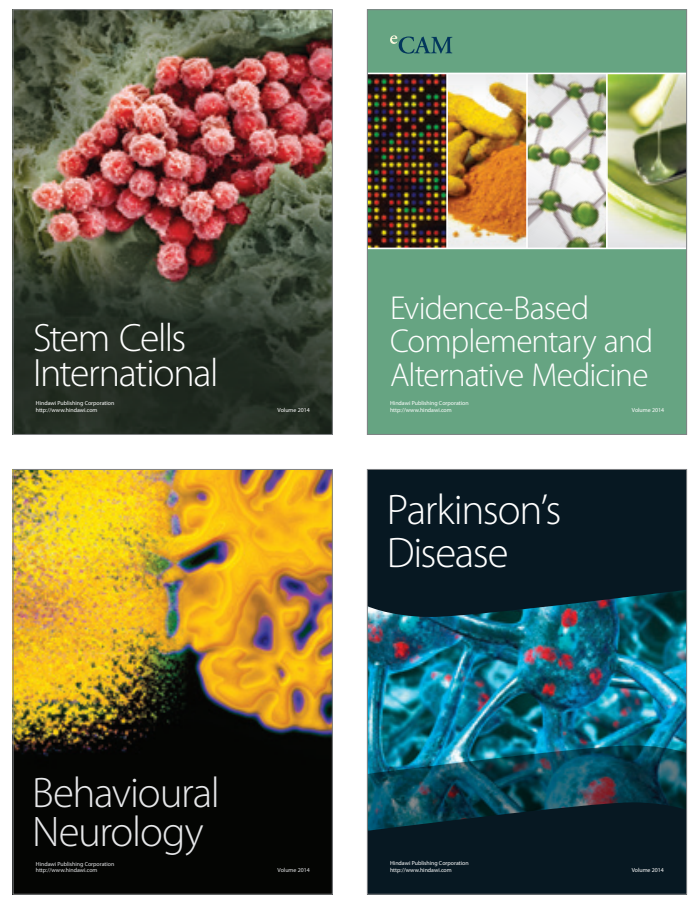
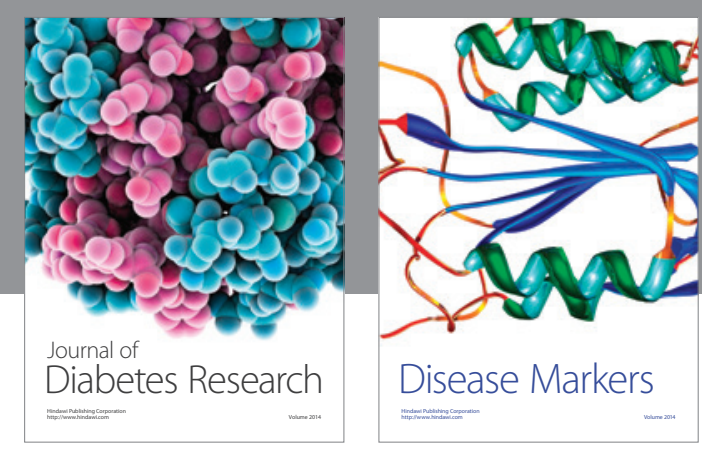

Disease Markers
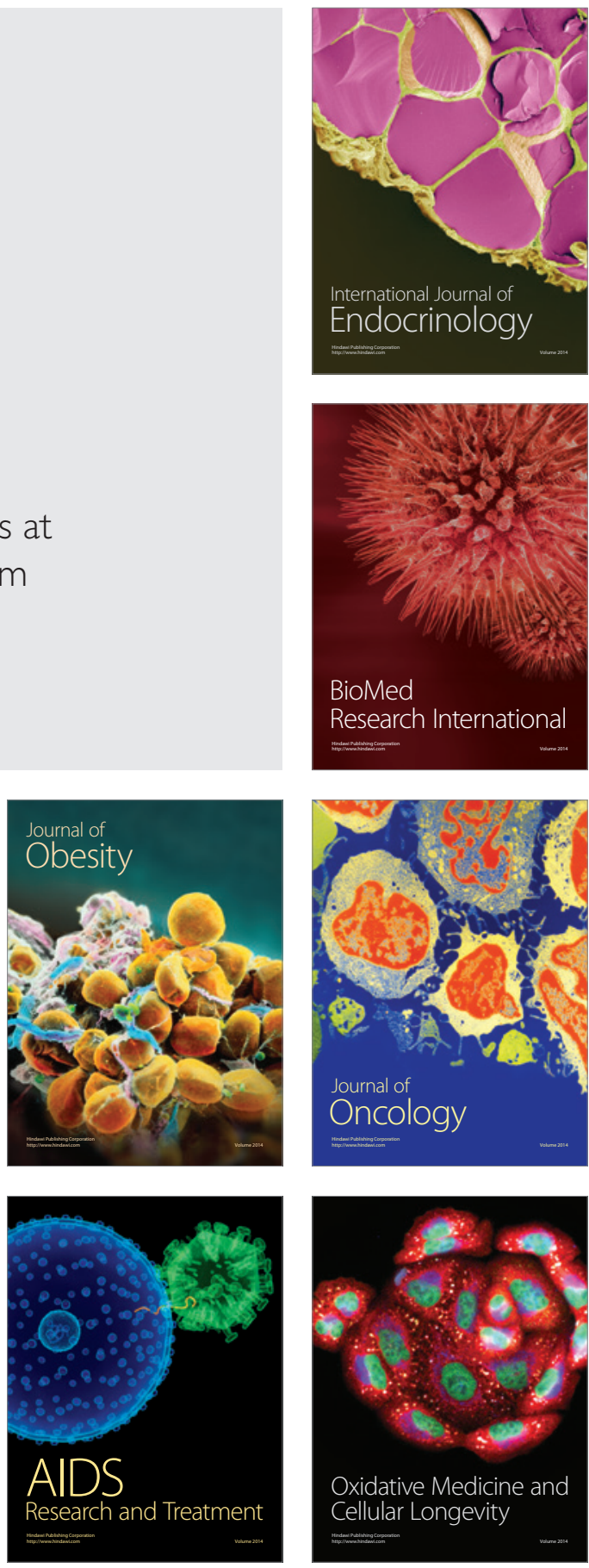